\title{
The Influence of CSR Practices on the Financial Performance of Microfinance Institutions in Togo
}

\author{
Akouvi Gadedjisso-Tossou ${ }^{1}$, Curwitch P'ham Bodjona ${ }^{1}$, Maman Tachiwou Aboudou ${ }^{1} \&$ Jean-Pierre Gueyie ${ }^{2}$ \\ ${ }^{1}$ Faculty of Economics and Management, University of Lomé, Lomé, Togo \\ ${ }^{2}$ School of Management, University of Quebec in Montreal, Montreal, Quebec, Canada \\ Correspondence: Jean-Pierre Gueyie, School of Management, University of Quebec in Montreal, Montreal, \\ Quebec, Canada. Tel: 1-514-987-3000. Ext. 2358. E-mail: gueyie.jean-pierre@uqam.ca
}

Received: December 10, 2020

Accepted: December 23, 2020

Online Published: January 30, 2021

doi:10.5539/ijef.v13n2p52

URL: https://doi.org/10.5539/ijef.v13n2p52

\begin{abstract}
Microfinance pursues a dual objective: reduce poverty (social performance) and ensure lasting profitability (financial performance). However, beyond these two performances, microfinance institutions (MFIs) have a social responsibility (CSR) towards their stakeholders. The main objective of this article is to measure the influence of the CSR practices of Togolese MFIs on their financial performance. The analysis is conducted over a sample of 60 Togolese MFIs, using the principal component analysis and generalized least squares techniques. The results show that CSR through the dimensions customer, employees and community positively and significantly impact on the financial performance of MFIs when measured by ROA, while the environment dimension has a negative significant influence.
\end{abstract}

Keywords: CSR, financial performance, MFI, Togo

\section{Introduction}

Microfinance covers the financial services offered to people who, traditionally have, difficulties in using or accessing financial services or are completely excluded from the formal financial system (Bennis, 2016). Generally, these are the poor. The microfinance sector is highly developed in developing countries because they have a large number of vulnerable people (Tchakoute-Tchuigoua, 2012). The authorship of microfinance is generally attributed to Professor Yunus, who founded the Grameen Bank (the village bank) in 1983 (Soulama, 2002; Blondeau, 2006). Professor Yunus' idea was to grant loans to micro-entrepreneurs to help overcome the financing problem that prevented them from carrying out small businesses. Consequently, the number of Microfinance Institutions (MFIs) has increased considerably over the years, but the funding has not followed the same chronology (Labie \& Montalieu, 2019).

Even if the main objective of MFIs is to improve the well-being of poor people by giving them access to financial services, two schools of thought clash on the best way to achieve this objective. These are the welfarists and the institutionalists (Morduch, 1999). The welfarist approach is based on the social responsibility theory. It measures the success of an MFI primarily by how it meets the needs of the poorest in the short term or in other words, how it reduces poverty. As for the institutionalist approach, it is based on the theory of contracts. It measures success by the viability of institutions, assuming that autonomous MFIs are likely to contribute significantly to income expansion and poverty reduction. Thought, the mission then becomes twofold. Alongside social performance which aims to reduce poverty, there is financial performance which allows the MFI to ensure sustainability. Is there a complementarity between these two performances? Does social performance influence financial performance or the reverse? These are questions that several authors have tried to answer including Adair and Berguiga (2010, 2014), Berguiga et al. (2017), Tlili (2019).

Most research in microfinance (Hartarska, 2005; Hartarska \& Nadolnyak, 2007; Tchakoute-Tchuigoua, 2010, 2012; Tchakoute-Tchuigoua \& Nekhili, 2012; Lapenu \& Doligez, 2007) has focused on the relationship between social performance (measured by a number of active borrowers for instance) and financial performance. Beyond social performance, the MFI must also assume its social responsibility. The nuance is that social performance is part of the integrated objectives of microfinance, it would be that directly indexed to the core activity of microfinance (which is help the poor), while social responsibility is that which goes beyond this main activity of 
the MFI (Ndonmbou \& Fouda, 2019). MFIs, therefore, have a Corporate Social Responsibility (CSR) towards their stakeholders because they operate in an environment on which their activity has both positive and negative repercussions.

From the observations in the districts of Lomé (Togo), we notice that MFIs are in constant relation with various actors towards whom they carry out several actions. These actors beyond the customers also include the employees, the neighborhood community who have expectations vis-à-vis the managers of the MFI and the environment. Some MFIs are keen to finance activities contributing to the development of communities such as school, market, soccer field constructions, sponsorship of amateur sport teams, etc. Other encourage their employees and specifically their staff to take part in cleaning activities in the city. These various activities undertaken by MFIs reflect their concern about CSR.

CSR practices can have lot of advantages for MFIs, but they may also generate additional financial and managerial costs. Therefore, their net impact on MFIs' financial performance is an empirical issue. Given this fact, the main objective of this article is to measure the influence of the CSR practices of Togolese MFIs on their financial performance. Our results show that CSR through the dimensions customer, employees and community positively and significantly impact on the financial performance of MFIs when measured by ROA, while the environment dimension has a negative significant influence.

The remainder of the paper is structured as follows: Section 2 is devoted to the literature review on CSR and financial performance in microfinance. Section 3 presents the sample and the methodology. Section 4 reports and discusses the results and Section 5 concludes.

\section{Literature Review on CSR and Financial Performance in Microfinance}

The concept of CSR has evolved over time since the first theoretical foundations, which date back to 1953 with the work of Mc Williams and Siegel (2001). They define CSR as a set of actions that improve the common well-being beyond the interests of the company and simple respect for the law. Starting from this definition, Mc Williams et al. (2006) consider that CSR constitutes a form of strategic investment while according to Campbell (2007), the company responsibility must go beyond its economic role to integrate social concerns and institutional pressures. Recently, ISO 26000 suggested a definition of CSR that is increasingly becoming consensus and which is a synthesis of the previous ones. It defines CSR as: “An organization's responsibility for the impacts of its decisions and its activities on society and the environment, through transparent behavior and ethics that: -contribute to sustainable development, including health and well-being of the society; -takes into account the expectations of stakeholders; -is in compliance with applicable law and consistent with international norms of behavior; and is integrated troughout the organization and practiced in its relationships" (ISO 26000, 2010).

Microfinance refers to the provision of financial services (generally credit and/or savings) to a poor clientele made up in particular of small self-employed workers (Ledgerwood, 1999; Robinson, 2001). Microfinance enables the poorest to diversify their sources of income to face risks (Guérin, 2000). MFI services currently range from microcredit, savings products, to insurance services and fund transfer in such a way that the question arises whether microfinance is not deviating from its objective that first, remains social. Indeed in some countries, the very strong growth in the microfinance supply and its apparent success barely compensate the contraction in the supply of credit to small businesses. This is the case for example in Mexico and India (Guérin, 2000). Also, the impact studies of microfinance in terms of poverty reduction are not very convincing (Ndonmbou \& Fouda, 2019).

Faced with this situation, innovations have been structured in recent years to bring out socially responsible microfinance (Guérin et al., 2009). Tools for evaluating and managing social performance (target audience, adaptation and quality of services, economic and social benefits for customers, etc.) have been developed in order to check and to support the implementation of the social objectives of MFIs.

Beyond these assessment tools, stakeholders provide food for thought to the entire sector to ensure that the microfinance does not turn away from its objectives but continues to reach an excluded population by providing useful services that have positive effects on their living conditions. Little by little, microfinance has seen a socially responsible sector built around it, starting by associating the various stakeholders, namely the MFIs themselves and their loan officers, investors as well as donors and also public authorities (Lapenu et al., 2008). CSR is therefore now included in the activities of MFIs. It induces additional management costs and one wonders whether these costs, compared to the indirect resources that CSR practices can generate, improve the financial performance of the MFI. 
Like CSR, the concept of performance in microfinance has different meanings depending on the contexts of use and the interests of the actors. But generally in the field of performance management it is a contingent and multidimensional notion which can be assimilated to the measurement of income (Marmuse, 1997). The objective of MFIs is to achieve the best possible performance, which can be achieved when they manage to reconcile social performance by reducing poverty and financial performance by ensuring sustainable profitability (Adair \& Berguiga, 2014). However, these two requirements give rise to a debate between two opposing currents of thought: welfarists argue the social requirement of targeting the poorest and improving their living conditions, institutionalists defend the economic requirement of profitability and the viability of the institution. These two approaches respectively of welfarists and institutionalists are subject to several criticisms. The first approach is confronted with the problem of viability and sustainability brought about by subsidies, low reimbursement rates and increased operating costs. The second approach favors a clientele of micro-entrepreneurs very close to the poverty line ( $\$ 2$ per day) to whom high interest rates are applied to ensure the financial autonomy of MFIs (Adair \& Berguiga, 2010). This "microfinance schism" (Morduch, 1999) refers to the trade-off between targeting the poor and the profitability of MFIs.

\section{Research Methodology}

\subsection{Sample and Data}

The sample in this study is made up of 60 MFIs operating in Togo. These include private companies, NGOs and cooperatives. MFIs' financial statements are provided to us by CASIMEC-Togo (Note 1). The other data are collected through a closed form (five points Likert scale) questionnaire. The questionnaire was administered to Togolese MFIs managers. 103 MFIs legally operating throughout the Togolese territory were surveyed. 60 of them gave valid answers representing a percentage of $58.25 \%$.

\subsection{The Dependent Variable}

The dependent variable is a measure of financial performance. The financial performance of MFIs is measured by indicators of profitability and financial viability (Tchakoute-Tchuigoua, 2010 and 2012; Adair \& Berguiga, 2010; Ndonmbou \& Fouda, 2019). Private MFI companies are much more concerned with maximizing the return on their capital. However, in NGOs and cooperatives, the emphasis is rather on the maximum number of poor people to reach. Faced with this heterogeneity of institutional form, the most common measure of financial performance is the return on assets (ROA) because it takes into account financing structures and facilitates the comparison between the different forms of MFIs. Financial viability is measured by operational self-sufficiency (OSS). It reflects the ability of the MFI to continue its activities without future subsidy. To measure the repayment capacity of customers in MFIs (Wesselink, 1995), we add a third measure of financial performance, the 90-day portfolio at risk (PAR90).

\subsection{CSR Constructs (Independent Variables)}

CSR practices constitute our explanatory variable. The dimensions of these practices relate to customers (CUST), employees (EMPL), the community (COMM) and the environment (ENVI). We used the confirmatory principal component analysis (confirmatory PCA) to build these CSR constructs, from items collected through the questionnaire. For a dimension in each MFI, we assigned a score ranging from "no item is taken into account" (strongly disagreeing) to a maximum of "all the variables are taken into account" (completely agree). Then we reduced this number to a value between 1 and 5 by dividing it by the total of the items of the dimension. This method of measuring CSR has been successfully used several times in the literature (Edmondson \& Carroll, 1999; Angelidis \& Ibrahim, 2004).

Two control variables are added to our list of explanatory variables. These are the logarithm of total assets to proxy the size, and the debt to equity ratio, to control for leverage.

The description of all the variables is presented in Table 1. 
Table 1. Description and operationalization of the main variables

\begin{tabular}{|c|c|c|}
\hline & Identity of the variable & Definition \\
\hline \multirow{3}{*}{$\begin{array}{l}\text { Financial } \\
\text { performance }\end{array}$} & $\begin{array}{l}\text { Economic profitability or Return on } \\
\text { Asset }(R O A)\end{array}$ & $\begin{array}{l}\text { (Net operating income) / Total assets. } \\
\text { Measure of the MFI's ability to use its assets to generate returns. }\end{array}$ \\
\hline & Operational self-sufficiency (OSS) & $\begin{array}{l}\text { (Financial income) / (financial expenses + allocations to provisions } \\
\text { for bad debts + operating expenses). } \\
\text { Capacity of the MFI to cover its costs with its operating income. }\end{array}$ \\
\hline & 90 Day Portfolio at Risk (PAR90) & $\begin{array}{l}\text { (Outstanding loss with at least one unpaid maturity of more than } \\
90 \text { days) / (gross outstanding loan portfolio). }\end{array}$ \\
\hline \multirow{4}{*}{ CSR } & Client (CUST) & $=\frac{\sum_{j=1}^{k} \text { Score } j}{\mathrm{k}}$ \\
\hline & Employees $(E M P L)$ & $=\frac{\sum_{j=1}^{k} \text { score } j}{\mathrm{k}}$ \\
\hline & Community (COMM) & $=\frac{\sum_{j=1}^{k} \text { Score } j}{\mathrm{k}}$ \\
\hline & Environment $(E N V I)$ & $=\frac{\sum_{j=1}^{k} \text { score } j}{\mathrm{k}}$ \\
\hline \multirow[t]{2}{*}{ Control Variables } & Size (SIZE) & Ln(total assets) \\
\hline & Leverage $(L E V)$ & Debt/Equity \\
\hline
\end{tabular}

Source: The authors. $\mathrm{K}$ is the numbers of items in the construct.

\subsection{The Regression Model}

To test the link between CSR practices and financial performance, we carried regressions through the following econometric specification:

$$
Y_{i}=\alpha+\beta_{1 i} C U S T_{i}+\beta_{2 i} E M P L_{i}+\beta_{3 i} C_{C O M M}+\beta_{4 i} E N V I_{i}+\beta_{5 i} S I Z E_{i}+\beta_{6 i} L E V_{i}+\varepsilon_{i}
$$

where $\mathrm{Y}$ is one of the dependent variable (ROA, OSS and PAR90), CUST, EMPL, COMM, ENVI are the explanatory variables: customer, employee, community and environment; SIZE and LEV (leverage) are the control variables, $\alpha$ and $\beta$ are the parameters of the model to be estimated and $\varepsilon$ is the random error term.

\section{Results and Discussions}

\subsection{Descriptive Analysis}

Table 2 reports the results of the descriptive analysis.

A factor analysis was performed to verify the psychometric quality of the CSR constructs used. The amount of inertia recovered is $73 \%$. Some items were eliminated through successive iterations. The final KMO value is 0.64 .

The first factor obtained is the customer dimension. The value of Cronbach's alpha is 0.77 . This factor includes items relating to the use of the mother tongue in the process of granting credit to customers, the precision of the real interest rate disclosed to customers and the monitoring and evaluation of the objectives of the credits granted. The second factor includes items that refer to the employee (having mechanisms to promote good interactions for employees, rewarding employees based on their skills, having a good and harmonious work climate in the MFI, take out health insurance for employees and have accident response plans). The reliability analysis provides a Cronbach's alpha of 0.72 . The third factor is, obviously, the community dimension. The items which are strongly linked to it consist in "voluntarily attending community activities which give meaning to the quality of life" and "financing social works". It has a reliability of 0.69 . The fourth factor, the environmental dimension is the one that contributes the least to the formation of CSR in terms of the percentage of inertia recovered. It is strongly correlated with the items "sponsor projects that protect and approve the quality of the environment", "reduce ink consumption for photocopiers and printers" and "reduce energy consumption". The reliability analysis gives a value of Cronbach's alpha of 0.64 , it is relatively low but this can be admitted given the relatively small size of the sample. 
Table 2. Items and constructs of CSR

\begin{tabular}{|c|c|c|c|}
\hline Constructs & Items & Abbreviation & Chronbach's alpha \\
\hline \multirow{3}{*}{$\begin{array}{l}\text { Customers } \\
(C U S T)\end{array}$} & Use the mother tongue in the process of granting credit to customers & USE MOTH TONG & \multirow[t]{3}{*}{0.77} \\
\hline & Specify the real interest rate to customers & RATE PRECISION & \\
\hline & Monitor and evaluate the objectives of the credits granted & CRED EVAL MONI & \\
\hline \multirow{5}{*}{$\begin{array}{l}\text { Employees } \\
(E M P L)\end{array}$} & Have mechanisms to promote good interactions for employees & EMPL INTER MECH & \multirow[t]{5}{*}{0.72} \\
\hline & Reward employees based on their skills and results & REWA EMP RESU & \\
\hline & Have a good and harmonious working climate in the MFI & HARM WORK CLIM & \\
\hline & Subscribe employees to health insurance & EMP HEALTH INS & \\
\hline & Have contingency plans in the event of an accident & ACCID CONT PLAN & \\
\hline \multirow{2}{*}{$\begin{array}{l}\text { Community } \\
(C O M M)\end{array}$} & $\begin{array}{l}\text { Voluntarily attend community activities that give meaning to the } \\
\text { quality of life }\end{array}$ & COMM ACTI ATTE & \multirow[t]{2}{*}{0.69} \\
\hline & Fund social works & SOCIAL FINAN & \\
\hline \multirow{3}{*}{$\begin{array}{l}\text { Environment } \\
(E N V I)\end{array}$} & $\begin{array}{l}\text { Sponsor projects that protect and approve the quality of the } \\
\text { environment }\end{array}$ & SPONS ENVI PROJ & \multirow[t]{3}{*}{0.64} \\
\hline & Reduce ink consumption for copiers and printers & REDU INK CONS & \\
\hline & Reduce energy consumption (water, electricity) & REDU ENER CONSO & \\
\hline
\end{tabular}

Source: Our surveys.

\subsection{Regression Estimation Results}

Table 3 summarizes the results obtained from the regressions.

Using the $R O A$ as a performance indicator, it can be seen from the results in Table 3 that the effect of CSR is somewhat felt. The value of the adjusted $\mathrm{R}^{2}$ is 0.128 . This means that the variation in $R O A$ is explained at a rate of $12.8 \%$ by the variation in societal actions and the control variables. An examination of the estimators inherent in each of the four dimensions of CSR shows that the customer dimension produces a positive and significant effect $(\mathrm{p}<5 \%)$ on financial performance measured by the ROA. This result is predictable because the quantitative measure (ROA) and the perceptual measure (customer dimension of CSR) tend to converge. The regression coefficient relating to the Employee dimension is positive and significant ( $<<5 \%)$. Community actions strongly positively impact on ROA. The coefficient of COMM is positive, and significant at $1 \%$ level $(\mathrm{P}<$ $1 \%)$. Community residents appreciate the social actions of companies, and this is reflected in ROA. The fourth dimension, $E N V I$, is significant too ( $1<5 \%$ ) but is negative.

For the other two proxies of performance (OSS and PAR90), there is a neutral effect of CSR on financial performance. The coefficient of all the four dimensions of CSR are not significant, and the adjusted $\mathrm{R}^{2}$ has a very low and insignificant value.

Table 3. Results of the regression of CSR measures on financial performance proxies

\begin{tabular}{llll}
\hline & ROA & OSS & PAR90 \\
\hline Constant & -0.060 & $-0.127 * *$ & -0.219 \\
& $(1.277)$ & $(2.842)$ & $(0.377)$ \\
CUST & $0.028^{* *}$ & 0.085 & 0.093 \\
& $(2.0561)$ & $(0.463)$ & $(0.498)$ \\
EMPL & $0.226^{* *}$ & 0.245 & 0.025 \\
& $(1.98)$ & $(1.260)$ & $(0.126)$ \\
COMM & $0.515^{* * *}$ & 0.039 & 0.047 \\
& $(2.924)$ & $(0.201)$ & $(0.240)$ \\
ENVI & $-0.077 * *$ & 0.000 & -0.028 \\
& $(-2.0462)$ & $(0.002)$ & $(-0.151)$ \\
SIZE & 0.127 & 0.017 & $0.011 * * *$ \\
& $(0.015)$ & $(0.019)$ & $(0.326)$ \\
LEV & 1.190 & 0.154 & 0.105 \\
& $(2.601)$ & $(0.035)$ & $(1.963)$ \\
Adjusted R2 & 0.128 & -0.067 & -0.120 \\
F & $2.178^{* *}$ & 0.500 & 0.190 \\
\hline
\end{tabular}

***: $1 \%$ significance; $* *: 5 \%$ significance; $*: 10 \%$ significance. T-statistics are in the parenthesis. 
The dependent variable are return on asset (ROA), operational self-sufficieny (OSS) and portfolio at risk for more than 90 days (PAR90). CUST, EMPL, COMM, ENVI are the four dimensions of CSR: customer, employee, community, environment. SIZE and $L E V$ are the control variables.

\subsection{Discussion of Results}

Taking customer expectations into account is the first CSR variable highlighted. The results show that the customer (CUST) is positively correlated with the financial performance measured by the ROA.

When the customer mother tongue is used in the credit granting process, he feels confident with the MFI. He, therefore, has no difficulty in continuing to use the services of this MFI. Very often the real rate of the loan includes costs (setting up credit, VAT, insurance, etc..) but this is generally ignored by customers. The accuracy of this rate is favorable to the MFI insofar as the client perceives it as the degree of honesty of the lender. Also when a MFI follows up to support its customer in achieving his objectives, the latter understands that he is important in the eyes of the MFI and that this fund provider cares about the success of his project. To the extent that the customer gains confidence, that he understands that the MFI is honest and that his projects have value in her eyes, his reaction can only be favorable to the MFI. This turns into an increase in the income of the MFI, leading, all else keep equal, to an increase in the ROA. These results are in perfect harmony with those of Ndonmbou and Fouda(2019) who show, through 85 MFIs in Cameroon, using an PCA method that customers' CSR practices positively influence the ROA of MFIs. Our results also show a positive influence of the customer variable on OSS and PAR90, but this effect is not significant.

Regarding the employee variable, our estimates show that this CSR variable has a positive influence on the financial performance of the MFIs in our sample. Thus, actions taking into account employee expectations lead to increased financial performance (measure by ROA) at the MFI. Entities often focus more on customers than on employees. However, it is important to note that it is employees who prospect for customers, collect deposits, grant loans, monitor repayments, etc. If these employees are not motivated, how can they serve customers as they should? Indeed when the working climate within the MFI is good, harmonious and when the MFI has mechanisms to promote good interactions for employees, the work is much more pleasant. Likewise, when employees are rewarded for their skills and performance, it follows that everyone wants to give its best and the best results of the employees also lead to that of the MFI. When a concern lies in taking into account the health of employees, this leads to a decrease in absence rates for sick leave. So when the MFI subscribes employees to health insurance and has accident response plans, the staff would be much more productive in terms of serving clients and thereby increasing the financial performance of the MFI. Similar results were found by Ndonmbou and Fouda (2019) and Zana and Sehic (2016). First, by measuring the care granted to the personnel by health insurance for the benefit of the staff and by the working conditions of the staff, they find that there is a positive relationship between meeting staff expectations and MFI performance. Second, by adopting the content analysis methodology they found that there was a positive relationship between employees' good perception of their company and its reputation.

The community variable in general has a positive influence on financial performance. More specifically, this relationship is significant when financial performance is measured by $R O A$, but not significant for other measures of financial performance (OSS and PAR90). Note that these are similar to those obtained with the customer and employee variables. Voluntarily attending community activities that give meaning to the quality of life and financing social works are what the community expects from MFIs established in their territory. By participating in the social life of the community, the MFI acquires more and more customers and a customer would prefer to use the services of an MFI that is interested in community life than an MFI that does not worry about it. Therefore taking the community into account means having access to more and more customers and when these customers are well served, the results obtained in the regression of the customer variable with financial performance follow directly. Our results converge with those of Ndonmbou and Fouda (2019) who find that financial self-sufficiency is positively influenced by the proportion of expenditure allocated to social works. But contrary to our results they find that the proportion of expenditure allocated to social works is negatively correlated with the ROA but not significantly. This discrepancy in the results may be because this author combined the community and environment variables, which may not show the real effect of each of these variables.

Our results are mixed when the environmental dimension of CSR is considered. The results of our estimates show that the influence of taking the environment into account is negative and significant on the financial performance measured by the ROA. MFIs are not companies whose activities have a direct influence on the environment like industrial companies, for example. At the MFI level, this impact may be indirect or may not 
even exist. Supporting projects that protect the quality of the environment entails a cost as long as in return they have no profit. This results in additional costs which decrease the results of the MFI and consequently the ROA. Also, the results of taking into account the environment on the OSS and the PAR90 are not significant; environmental performance is not significantly linked to these financial performance proxies (Allet, 2014).

\section{Conclusion}

The purpose of this research is to question the contribution of Corporate Social Responsibility to the Financial Performance of Togolese MFIs. The aim was to test the validity of the approaches anchored in the North American literature (Business \& Society and Business Ethics) and which underlie the impact of CSR on financial performance: the "Social impact hypothesis". The originality of our approach is that it borrows a measure of CSR which is both theoretically proven (Carroll, 1979) and psychometrically valid (Maignan et al., 1999). It uses the available accounting measures (Aupperle et al., 1985) and additional data collected through a closed for questionnaire.

The main results of our regressions show that CSR in customer, employee and community variables globally and positively influences the financial performance of MFIs measured by ROA. Operational self-sufficiency (OSS) and 90-day portfolios at risk (PAR90) are neutral.

From a managerial standpoint, this work helps to enlighten the leaders of Togolese MFIs on the repercussions of the social actions that they may undertake, CSR being positively correlated with financial performance. Managers are called upon to become more involved in the social aspect since this investment is both profitable for the company and at the same time contributes to social well-being. CSR could thus take the form of a strategic asset (Waddock \& Graves, 1997).

However, this work has some limitations. The first limitation relates to the nature of the sample. Indeed, its size is relatively small. The second limitation relates to the financial performance indicators used in the analysis. The fact of referring only to quantitative performance measures is a reductive vision of the scope of the construct. It would be relevant to associate the quantitative variables retained with more perceptual variables allowing us to learn about the apprehensions that the leaders of Togolese MFIs have about the business climate.

\section{References}

Adair, P., \& Berguiga, I. (2010). Les facteurs déterminants de la performance sociale et de la performance financière des institutions de microfinance dans la région MENA: Une analyse en coupe instantanée. Région et Développement, 32, 91-119.

Adair, P., \& Berguiga, I. (2014). How do social and financial performance of microfinance institutions interact? A panel data study upon the MENA region (1998-2011). Saving and Development, 38(1), 7-26.

Allet, M. (2014). Why do microfinance institutions go green? An exploratory study. Journal of Business Ethics, 122, 405-424. https://doi.org/10.1007/s10551-013-1767-2.

Angelidis, J., \& Ibrahim, N. (2004). An exploratory study of the impact of degree of religiousness upon an individual's corporate social responsiveness orientation. Journal of Business Ethics, 51, 119-128. https://doi.org/10.1023/B:BUSI.0000033606.27489.bf

Aupperle, K. E., Carroll, A. B., \& Hatfield, J. D. (1985). An empirical examination of the relationship between corporate social responsibility and profitability. Academy of Management Journal, 28(2), 446-463. https://doi.org/10.2307/256210.

Bennis, L. (2016). Les institutions de la microfinance entre la responsabilité sociale et la performance financière: Cas des associations de micro-credits. European Scientific Journal, 12(1). https://doi.org/10.19044/esj.2016.v12n1p372.

Berguiga, I., Adair, P., \& Ben, S. Y. (2017). La performance sociale et financière des institutions de microfinance islamique: Une analyse en panel sur la région MENA (2004-2015). Conference Paper. https://www.researchgate.net/publication/327178126.

Blondeau, N. (2006). La microfinance un outil de développement durable? Etudes, 2006/9(405), 188-198.

Campbell, J. L. (2007). Institutional analysis and the paradox of corporate social responsibility. The American Behavioral Scientist, 49, 925-938. https://doi.org/10.1177/0002764205285172.

Carroll, A. B. (1979). A three dimensional conceptual model of corporate social performance. Academy of Management Review, 4(4), 497-505. https://doi.org/10.5465/amr.1979.4498296.

Carroll, A. B. (1999). Corporate social responsibility. Evolution of a definitional construct. Business and Society, 
38(3), 268-295. https://doi.org/10.1177/000765039903800303.

Edmondson, V. C., \& Carroll, A. B. (1999). Giving back: An examination of the philanthropic motivations, orientations and activities of large black-owned. Journal of Business Ethics, 19, 171-179. https://doi.org/10.1023/A:1005993925597.

Guérin, I. (2000). Microfinance dans les pays du Sud: Quelle compatibilité entre solidarité et pérennité? Revue d'Economie Financière, 56, 145-164. https://doi.org/10.3406/ecofi.2000.3818.

Guérin, I., Lapenu, C., \& Doligez, F. (2009). La microfinance est-elle socialement responsable? Introduction. Revue Tiers Monde, 2009/1(197), 5-16. https://doi.org/10.3917/rtm.197.0005.

Hartarska, V. (2005). Governance and performance of microfinance institutions in Central Eastern Europe and the Newly Independent States. World Development, 33(10), 1627-1643. https://doi.org/10.1016/j.worlddev.2005.06.001.

Hartarska, V., \& Nadolnyak, D. (2007). Do regulated microfinance institutions achieve better sustainability and outreach? cross country evidence. Applied Economics, 39(10), 1207-1222. https://doi.org/10.1080/00036840500461840.

ISO 26000. (2010). Retrieved from https://www.social-responsibility.at/definitions/iso-26000-2010/

Labie, M., \& Montalieu, T. (2019). Introduction. De la microfinance à l'inclusion financière. Mondes en Développement, 2019/1(185), 7-12. https://doi.org/10.3917/med.185.0007.

Lapenu, C., \& Doligez, F. (2007). Mesure des performances sociales: Les implications pour le secteur de la microfinance. Revue Internationale de l'Économie Sociale: Recma, 304, 46-62. https://doi.org/10.7202/1021531ar.

Lapenu, C., De Bruyne, B., \& Verhagen, K. (2008). Le rôle des investisseurs dans la promotion des performances sociales en microfinance. Dialogue Européen $\mathrm{N}^{\circ} 1$, Plateforme européenne de microfinance, Luxembourg, p. 121.

Ledgerwood, J. (1999). Microfinance handbook, an institutional and financial perspective. The World Bank, 18771, 304. https://doi.org/10.1596/978-0-8213-4306-7.

Maignan, I., Ferrell, O. C., \& Hult, G. T. M. (1999). Corporate citizenship: Cultural antecedents and business benefits. Journal of the Academy of Marketing Science, 27(4), 455-469. https://doi.org/10.1177/0092070399274005.

Marmuse, C. (1997). Performance. In P. Joffre, \& Y. Simon (Eds.), Encyclopedie de gestion (2nd ed.). Economica, 2194-2207.

McWilliams, A., \& Siegel, D. (2001). A within and between analysis of the relationship between corporate social responsibility and financial performance. Academy of Management Review, 26, 117-127. https://doi.org/10.5465/amr.2001.4011987.

McWilliams, A., Siegel, D., \& Wright, P. M. (2006). Corporate social responsibility: Strategie implications. Journal of Management Studies, 43, 1-18. https://doi.org/10.1111/j.1467-6486.2006.00580.x.

Morduch, J. (1999). The microfinance promise. Journal of Economic Literature, 37, 1569-1614. https://doi.org/10.1257/jel.37.4.1569.

Ndonmbou, M. M., \& Fouda, B. J. (2019). Pratiques de responsabilité sociétale des entreprises: Quel apport pour la performance financière des établissements de microfinance du Cameroun? Global Journal of Research in Business \& Management, 7(1), 524-539.

Robinson, M. S. (2001). The microfinance revolution: Sustainable finance for the poor. The Word Bank, 23250(1), 356. https://doi.org/10.1596/0-8213-4524-9.

Soulama, S. (2002). Microfinance, pauvreté et développement. CEDRES, Université de Ouagadougou, 185 pages.

Tchakoute Tchuigoua, H. (2010). L'influence des mécanismes de gouvernance sur la performance des institutions de microfinance d'Afrique Sub-saharienne. Solvay Brussels School of Economics and Management Centre Emile Bernheim. CEB Working Paper $N^{\circ}$ 10/026.

Tchakoute Tchuigoua, H. (2012). Gouvernance et notation des institutions de microfinance: Une étude empirique des institutions de microfinance africaines. Comptabilité-Contrôle-Audit, 18(1), 153-182. https://doi.org/10.3917/cca.181.0153. 
Tchakoute Tchuigoua, H., \& Nekhili, M. (2012). Gestion des risques et performance des institutions de microfinance. Revue d'Economie Industrielle, 138, 127-128. https://doi.org/10.4000/rei.5401.

Tlili, A. (2019). La microfinance dans la région MENA entre performance financière et performance sociale: étude de cas de 18 IMF. MPRA Paper No. 93594

Waddock, S., \& Graves, S. B. (1997). The corporate social performance-financial performance link. Strategic $\begin{array}{llll}\text { Management } & \text { Journal, } & \text { 303-319. }\end{array}$ https://doi.org/10.1002/(SICI)1097-0266(199704)18:4<303::AID-SMJ869>3.0.CO;2-G.

Wesselink, A. F. (1995). Monitoring guidelines for semi-formal financiel institutions active in small enterprise finance. Cahier de Recherche 9, BIT, Genève, Suisse.

Zana, \& Sehic, D. (2016). Employees' perceptions of corporate social responsibility: A case study of award Recipient. UDK/UDC: 005.35(497.6), 239-260.

\section{Note}

Note 1. Support and Monitoring Unit of Mutualist Institutions or Cooperatives of Savings and Credit of Togo.

\section{Copyrights}

Copyright for this article is retained by the author(s), with first publication rights granted to the journal.

This is an open-access article distributed under the terms and conditions of the Creative Commons Attribution license (http://creativecommons.org/licenses/by/4.0/). 